\title{
THE HAN PERIOD GLASS DISH FROM LAO CAI, NORTHERN VIETNAM
}

\author{
Brigitte Borell \\ Independent Scholar, Heidelberg, Germany \\ Email: b_borell_seidel@hotmail.com
}

\begin{abstract}
During the last decades, a total of sixteen glass vessels of previously unknown type, mainly small cups and a few shallow bowls, have come to light in Han period tombs in Guangxi, China. Made of a potash glass, these glass vessels were probably manufactured somewhere in the region of southern China or northern Southeast Asia. The shallow glass bowl found in Lao Cai, in the upper Red River valley, northern Vietnam, is clearly related to this group. The date from the first century BCE to the first century CE, suggested for the Lao Cai find context, correlates with the dates of the Guangxi tombs in which glass vessels were found.
\end{abstract}

\section{INTRODUCTION}

The glass dish (Figures 1-6) was found, together with more than forty other objects, most of them bronzes, in Lao Cai town in 1993, during construction work for an extension of the market area Coc Leu II (Khu B Cho Coc Leu). The finds were brought to the museum in the following year (Phạm 1997a. Phạm 1997b. Reinecke et al. 1999: 38 n.127). Lao Cai is situated in northern Vietnam, in the upper Red River valley, about $360 \mathrm{~km}$ from the sea. Numerous finds on both sides of the Red River document that its valley was a link between the archaeological culture of Dong Son, centred in the Red River delta and the lower valleys of the $\mathrm{Ma}$ and $\mathrm{Ca}$ rivers, and that of Dian farther north in Yunnan (Allard 1999: 83-84. Reinecke et al. 1999: 37-38. Higham 2002: 278. Murowchick 2002: 176).

\section{ARCHAEOLOGICAL CONTEXT}

Five find groups were discovered in Lao Cai at that time, all spectacular because of their rich inventory of bronze drums and other objects of high prestige value regarded as status markers. Group 5, which includes the glass dish, was found when a hill was levelled near the western bank of the Red River, just south of its confluence with an eastern tributary, the Nam Thi river (Nanxi river in Chinese). No details about the archaeological context were reported. However, in all likelihood, the contents of group 5 , as well as those of the other groups, are objects from burials. Group 5 is particularly rich and might represent either an exceptionally wealthy élite burial or, alternatively, more than one burial of high status.

The seven Heger I type bronze drums are the most prominent items in the assemblage of group 5 (Pham 1997a: nos.13-19 fig. $7=$ no. 13 , and fig. $8=$ no.17). In addition, there were nine horned bells, three of them with inscriptions in Chinese characters. The inscription of one of those (Nguyễn 2007: 46; 50, illustrations 8-10), cast in low relief, reads 除禍致吉福 “Ward off calamity, bestow good fortune". Such musical instruments, like the bronze drums and bronze bells, were highly valued élite status symbols (Yun 2001: 116. Falkenhausen 2001: 222-224. On the distribution area of horned bells in southern China and Vietnam, see also Jiang 1984). Worth mentioning are also one jade $b i$ disk, part of a crossbow mechanism, and at least one ge halberd and four iron swords. The more than seventeen bronze vessels included one eared cup, two cylindrical lian vessels, one ding tripod cauldron, and one basin with two incised fish in the interior (Pham 1997a: 39. Phạm 1997b: 46. Phạm Minh Huyền, pers. comm. December 2009). Many of the artefacts of group 5 find parallels in burials of the Western and Eastern Han period in Guangxi and Guangdong, suggesting a date for the interment of group 5 within a time span from the first century BCE to the first century CE (Phạm 1997a: 62-63. Phạm 1997b: 56).

\section{DESCRIPTION OF THE GLASS DISH}

Only part of the glass dish survived. This is probably due to the accidental discovery of the finds during construction work. The break appears to be recent as it shows no signs of weathering. However, the one fragment is large enough to allow its reconstruction as a shallow bowl with a rim diameter of about $13.5 \mathrm{~cm}$ (Figures 1-3) and an estimated height of at least $2.6 \mathrm{~cm}$. It is made of translucent pale greenish glass still preserving a silky-matt lustre. The upright rim has a flattened edge sloping obliquely inward. The convex sides curve gently toward the bottom which was apparently not flat, but also slightly convex. The wall measures in thickness about $4 \mathrm{~mm}$, at the rim slightly less: about 3.0 to $3.5 \mathrm{~mm}$. The wall thickness clearly increases towards the bottom to at least $5 \mathrm{~mm}$. The bowl was probably formed from hot and viscous glass pressed into a mould.

A thin layer of transparent brownish weathering is noticeable on the interior and exterior surfaces (Figures 1 

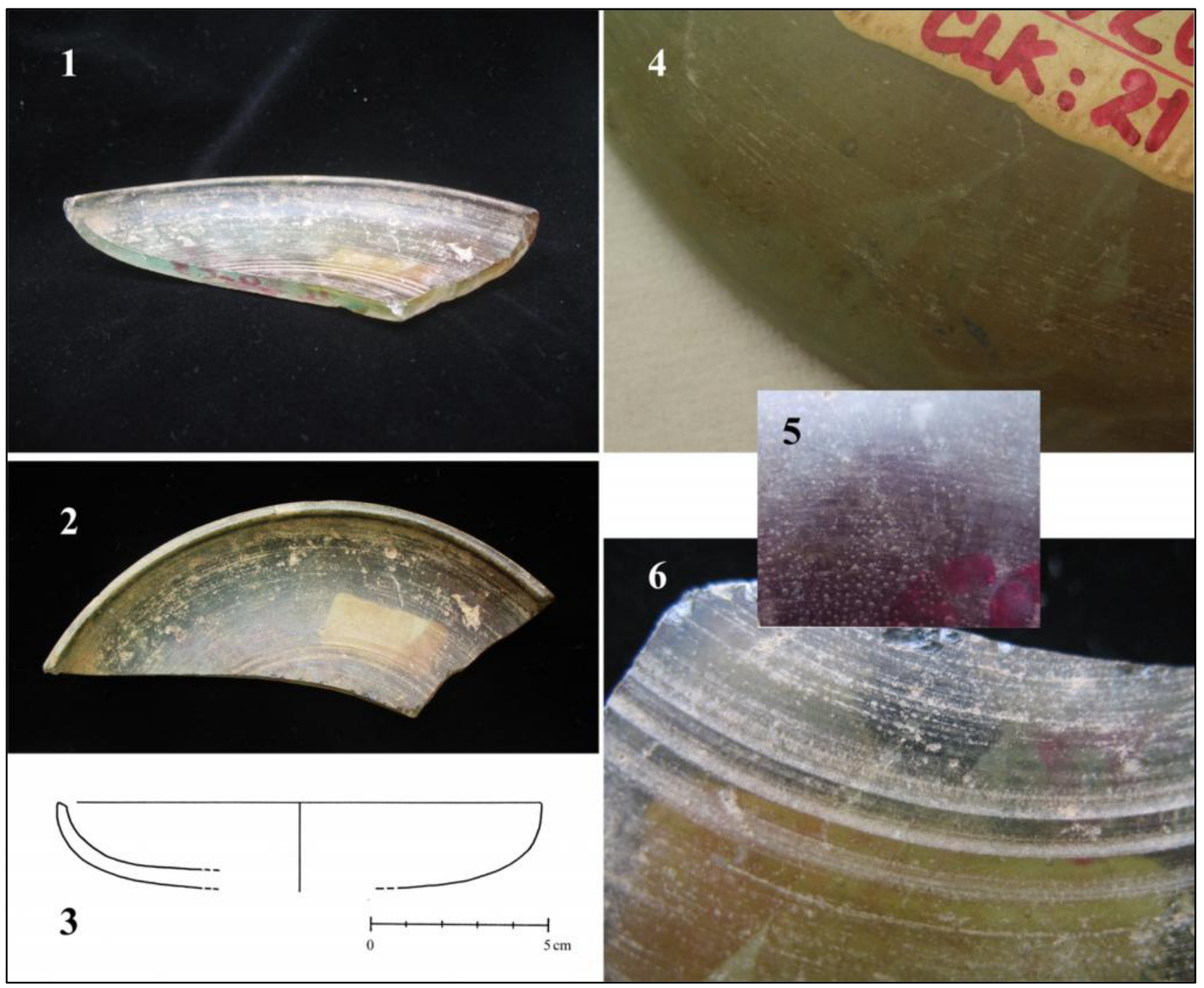

Figures 1-6: 1-2. inside of glass bowl. 3. profile drawing. 4-5. detail of exterior. 6. detail of interior

and 4). The glass contains many small bubbles that, as is visible in the break, seem to form a layer within the wall. A concentration of numerous small bubbles, limited to a small area, appears just underneath the exterior surface (Figure 5).

Noticeable are concentric marks on both exterior and interior surfaces (Figures 4-6). Apparently, these are unintentional marks resulting from the manufacturing process. It is still an open question precisely which process generated these marks. Current research on ancient glass vessels offers two differing explanations. The one favours their originating from a rotary polishing of the finished glass vessel in a cold state. Alternatively, the concentric marks are explained as the remains of 'hot scratches' generated by a rotary movement during the hot-forming process in a mould; microscopic particles on the mould surface rubbed against the skin of the hot glass leaving 'hot scratches' - with a characteristic horseshoe pattern which only partly re-melted, leaving the marks now visible (Lierke 2002. Lierke 2009: 30-35; 101-103). In any case, the effects of weathering would considerably contribute to the present noticeable appearance of the marks.

Similarly, the visual impression of three intentional concentric 'bands' on the interior of the Lao Cai dish, near the centre of the bowl (Figure 6), might be misleading. It is difficult to decide whether they were in actual fact intended as three decorative bands made by grinding, as the surface is smooth and the concentric 'bands' lack clearly defined boundaries, or whether they just result from the combined effects of weathering on a concentration of concentric marks originating from the manufacturing process. Comparable concentric zones with the characteristic concentric marks and heavy beige-brownish weathering are also to be observed on the other shallow bowls of the Guangxi group. Further technological investigations would be highly desirable.

\section{GROUP OF SIMILAR GLASS VESSELS}

In shape and other characteristics, the glass bowl from Lao Cai is very similar to shallow bowls found in Guang- 


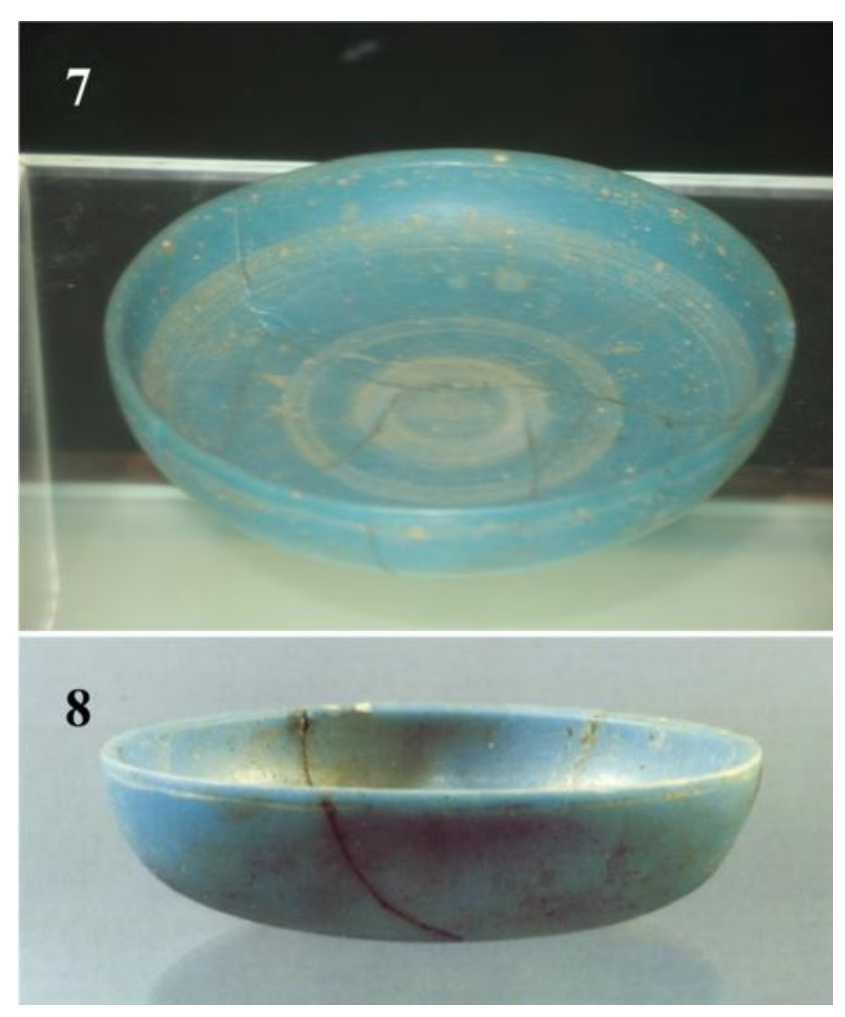

Figures 7-8. 7. Shallow glass bowl from tomb 1 at Muzhuling, Hepu. 8. Shallow glass bowl from tomb 5, Qichelu, Guixian. Courtesy of liuliart.

xi (Figure 7-8) (Kwan 2001: 48 fig.50,4-5). These shallow bowls and some small cups made of potash glass form a group of glass vessels unearthed from tombs in Guangxi dated to the late Western Han period (206 BCE $25 \mathrm{CE}$ ) and the Eastern Han period (25 - $220 \mathrm{CE}$ ) (Kwan 2001: 48 fig.50,2-9. Huang 2006. Borell 2010. Borell 2011). At present, sixteen glass vessels of this group are known from Guangxi. They were found mainly in two areas in Guangxi province: in Hepu near the coast, and in Guixian further inland. A recently found glass vessel from Bac Ninh province in northern Vietnam might also belong to this group (Hirano 2008: 46).

All of the glass vessels of this group are relatively thick-walled, the walls average between 3 to $4 \mathrm{~mm}$ thick. Usually, these glass vessels are regarded as pressed in a mould (An 1987: 6. Huang 2005: 197. Borell 2012: 493494). It appears that the technique employed to make the characteristic Chinese ornaments, like the glass bi disks and others, was the pressing of hot glass into moulds. Simon Kwan (2001: 51-54 and 282; ib. $51-52$ and fig.61,1-2) made some interesting observations on pressmoulded glass objects preserved together with their moulds. The side which was in contact with the mould is smooth, whereas the other side, which took the pressing, is rough (On the technique of press-moulded ancient glass, see also Lierke 2009: 5, 27-35, 56-60, resp. 92, 100-103, 110-112 for the English version).

The majority of these glass vessels are small cups with three horizontal ribs. Shallow bowls of a plain shape similar to the Lao Cai vessel were found in two tombs in
Guangxi. The one (Figure 7) from Muzhuling in the Hepu area is made of semi-opaque azure-blue glass (D rim 12.7 $\mathrm{cm})$; the tomb has been dated to the Wang Mang interregnum (9 - $25 \mathrm{CE}$ ) based on the da quan wu shi coins which were introduced in the year 7 CE (Huang 1992). However, the evidence of the coins found in the tomb provides only a terminus post quem. The tomb cannot be earlier than the year $7 \mathrm{CE}$, it might be contemporaneous with the coins or later. Xiong Zhaoming (pers.comm. March 2009), who examined the grave goods of this tomb, suggests a date already in the early Eastern Han period. In any case, we arrive for Muzhuling tomb 1 at a date in the early or mid-first century CE. The other glass bowl (Figure 8), found in Guixian further inland, in a tomb of the Eastern Han period $(25-220 \mathrm{CE})$, is made of semiopaque turquoise glass (D $\operatorname{rim} 12.7 \mathrm{~cm}$ ). A third example of such a shallow bowl, now in the Musée Guimet in Paris, is also made of semi-opaque turquoise glass (D rim $13.0 \mathrm{~cm}$ ) (Figure 9). The Lao Cai bowl shares with these three bowls also such characteristic details as the flattened oblique edge of the rim, and with the Guixian and Guimet bowls, the convex rounded bottom. On the inside, the bottoms of the Guixian and Guimet bowls are less curved, but slightly levelled, due to the increased thickness of the glass, as was also the case in the Lao Cai bowl. The shallow glass bowl from Lao Cai clearly may be assigned to this group of rare and precious glass vessels.

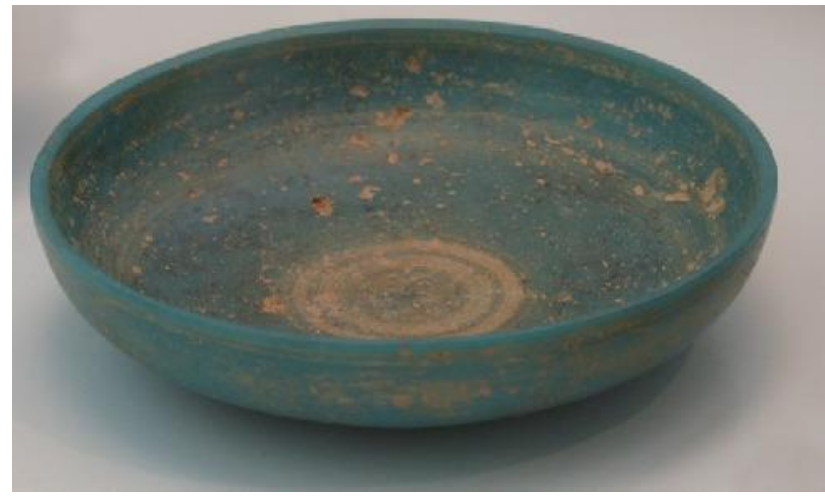

Figure 9. Shallow glass bowl, Musée Guimet MA 12095, Paris

Most of the Guangxi cups and shallow bowls are made of strongly coloured blue or greenish-blue glass. However, some of them are made of translucent glass of natural aqua colour, with a bluish or greenish tint produced by iron impurities, similar to the glass of the Lao Cai bowl. These are, for instance, the cup from Wenchangta, the stemmed cup and saucer from Nandoucun, and a small cup from Guixian (Kwan 2001: 48 fig.50, 2.7 and 9. Huang 2006: figs.1 and 2). This applies also to the cup formerly in the Shorenstein collection, San Francisco (Borell 2010: fig.10) and to the glass cup from Bac Ninh, mentioned above, the latter made of a translucent glass with a greenish tint (Yuko Hirano, pers.comm. Dec. 2009). 


\begin{tabular}{|c|c|c|c|c|c|c|c|c|c|}
\hline & 1 & 2 & 3 & 4 & 5 & 6 & 7 & 8 & 9 \\
\hline $\mathrm{SiO}_{2}$ & 76.78 & 79.69 & 73.69 & 74.62 & 78.29 & 76.28 & 74.94 & 77.70 & $X X X$ \\
\hline $\mathrm{Na}_{2} \mathrm{O}$ & 0.68 & & 1.58 & 1.56 & & 0.27 & 0.16 & & \\
\hline $\mathrm{CaO}$ & 0.94 & 0.41 & & 0.68 & 0.12 & 0.54 & 0.03 & & $X X X$ \\
\hline $\mathrm{K}_{2} \mathrm{O}$ & 14.94 & 16.22 & 16.53 & 16.01 & 17.28 & 15.43 & 15.99 & 16.80 & $X X$ \\
\hline $\mathrm{MgO}$ & 0.37 & 0.01 & 0.66 & 0.41 & & 0.47 & 0.15 & & \\
\hline $\mathrm{Al}_{2} \mathrm{O}_{3}$ & 3.41 & 2.14 & 5.68 & 5.36 & 1.99 & 3.28 & 4.16 & 3.17 & \\
\hline $\mathrm{Fe}_{2} \mathrm{O}_{3}$ & 0.92 & 1.36 & 0.73 & 0.71 & 0.56 & 0.47 & 0.60 & 0.78 & $x$ \\
\hline $\mathrm{TiO}_{2}$ & 0.27 & 0.22 & & & & & & & \\
\hline $\mathrm{Sb}_{2} \mathrm{O}_{5}$ & 0.11 & & & & & & & & \\
\hline $\mathrm{MnO}$ & 0.15 & & 0.69 & 0.64 & & & 0.01 & & \\
\hline $\mathrm{CuO}$ & 0.01 & & 0.25 & & 1.67 & 0.01 & 1.24 & 1.62 & \\
\hline \multicolumn{10}{|l|}{$\mathrm{CoO}$} \\
\hline $\mathrm{SnO}_{2}$ & 0.09 & & & & & & & & \\
\hline $\mathrm{PbO}$ & 0.4 & & & & & & & & \\
\hline $\mathrm{P}_{2} \mathrm{O}$ & 0.12 & & & & & & & & \\
\hline $\mathrm{BaO}$ & & & & & & & & & $x$ \\
\hline
\end{tabular}

Table 1: Chemical analyses of nine Han period glass vessels of the Guangxi group (wt \%). 1 Shorenstein Coll. (Brill 1999). 2 Wenchangta T.70 (Huang 1992). 3 Hongtouling T.11: 22 (Huang 2006). 4 Hongtouling T.11: 21 (Huang 2006). 5 Huangnigang T.1 (Huang 2006). 6 Fengliuling T.2: stemmed cup (Shi et al. 1987). 7 Fengliuling T.2: cup (Shi et al. 1987). 8 Guixian, Qiche Road T.5 (Huang 1992). 9 Guixian, Railway Station (Fan and Zhou 1991).

\section{CHEMICAL COMPOSITION OF THE GLASS OF THIS GROUP OF GLASS VESSELS}

So far, the chemical composition of the Lao Cai glass bowl has not been investigated. However, nine vessels of the Guangxi group have been analysed over the years with different methods (Table 1). They are made of a potash glass with a low lime content similar in composition to the majority of analysed glass artefacts from Guangxi (Li et al. 2009. Fu and Gan 2009). This glass composition is also known from northern Vietnam (Reinecke, et al. 2002: 189-200. Lankton and Dussubieux 2006: 136-137). Initially, it was thought that the Guangxi glass vessels were imports from western regions. This, of course, was ruled out by the chemical analyses, since potash glass was unknown in the Mediterranean region and in Western Asia at that time, but is rather a glass composition prevalent in Southeast Asia. Therefore, an alternative suggestion regarding the Guangxi glass vessels was that they were introduced from the "southern seas". However, the present state of knowledge strongly suggests a regional manufacture for the numerous potash glass artefacts excavated in southern and south-western China. The presence of thallium in ear spools of characteristic Chinese shape possibly points to a provenance of raw materials from Guizhou, either for the batch material, or at least for the cobalt as colouring agent (Brill and Shirahata 2009: 156-158). These considerations make it likely to assume a regional origin also for the Guangxi group of glass vessels in the area of northern Vietnam and southern China.

As I have argued elsewhere, the archaeological evidence finds further support in a Chinese written source referring to primary glass making as well as to the manufacture of glass bowls in this region. This reference is found in the Baopu zi nei pian (Inner Chapters of the Master who Embraces Simplicity), compiled by the Daoist philosopher and alchemist Ge Hong (Ge Hong (284343) 1985: chapter 2.22) toward the end of the Western Jin period (265-316 CE):

"The 'crystal' bowls, which are made in foreign countries, are in fact prepared by compounding five sorts of (mineral) ashes. Today, among the people of Jiao and Guang many obtained this method and make them."

It is of special interest that the term $z h u$, used by Ge Hong to denote the making of the bowls, is taken from the vocabulary used for casting metal; in this context it seems 
to imply that the bowls were formed by introducing hot glass into a mould. The two regions "Jiao" and "Guang" are the administrative units Jiaozhou and Guangzhou of the early third century CE, comprising the three former Han period commanderies in present-day Vietnam and the four in present-day Guangxi and Guangdong (Loewe 2004: 59 and 78 bottom, map).

Another Chinese text, written, about 300 CE by Wan Zhen, in his Nanzhou yiwu zhi (Record of Curiosities of the South) refers apparently to the source of potash, which was probably saltpetre, and occurs as a soil efflorescence in Southeast Asia and China:

"Glass (liuli) is basically made from stone; if you want to make vessels you temper it with 'natural ash' (zi ran hui). This substance has the appearance of yellow ash, and is found on the coast of the southern sea. It may also be used to wash clothes; when you use it, it is not necessary to soak the garment, you just throw it in the water and it becomes as slippery as a mossy stone. Without this ash, the other ingredients [of glass] will not melt."(After An 1987: 25, translated by Matthew Henderson).

With good reason, the potash glass, as well as the finished objects, like the Guangxi glass vessels, may be considered to be regional products. The working of the glass probably involved a larger number of glassworking centres. Possibly, one of the places where the Guangxi glass vessels were manufactured was in the area of Hepu, where, in Shiwan, remains of a Western Han town have been discovered (China Today, 2002). A likely alternative might be the area of the commandery of Jiaozhi (Giao Chi in Vietnamese), comprising the delta area of the Red River and part of its valley. According to the late Western Han census of the year $1 / 2 \mathrm{CE}$, Jiaozhi was by far the most densely populated commandery in the region - or the one with the most efficient administration (Loewe 2004: 64-65). Perhaps, future excavations might yield evidence for such glass workshops. Unfortunately, the promising name 'Go Thuy Tinh' as an archaeological site name in Lao Cai seems to refer to a glass factory of modern times (Nguyễn Mạnh Cường, pers.comm. March 2009). The Lao Cai glass bowl might have been presented as an object of high value to a lord in the upper valley of the Red River, where it was later included in his burial, among other high prestige grave goods. To judge from the wealth of the find groups in the Lao Cai area, in particular the presence of bronze drums - a total of nineteen drums was found - and other prestige objects such as a jade sword guard, a silver bowl, a mirror, and, not least, the glass dish, these must have been burials of a locally ruling élite, which indicates a major centre of power in the upper Red River valley (Phạm 1997a. Phạm 1997b).

\section{DISTRIBUTION OF THIS GROUP OF GLASS VESSELS}

Glass vessels of the Guangxi group seem to have a wide distribution. As I have shown elsewhere (Borell 2010: fig.3a-b), the fragment of a glass cup, its shape strikingly similar to the Guangxi cups, was found at Arikamedu (Figure 10), a port site on the south-east coast of India with abundant evidence for its trade connections with the Mediterranean world. It was found in a layer corresponding to Phase $\mathrm{C}$ in Vimala Begley's chronology (Begley 2004: 5-9), covering most of the first century BCE and possibly extending into the early first century $\mathrm{CE}$. This is well within the time range of the Guangxi cups. However, it should not be taken as directly dating the glass fragment from Arikamedu. Begley (2004: 8) rightly cautions against considering the suggested dates as "inflexible" because of "the uncertain factor of when a datable object arrived at the site and when it was discarded." Another limitation for dating is the disturbed character of the site (Begley 2004: 1). In contrast to the well-known flow of Mediterranean glass vessels along the maritime trade routes to eastern destinations as far as China, for example, the ribbed bowl of mosaic glass found in a first century CE context in Jiangsu province (Borell 2010: fig.1), this find from Arikamedu seems to be archaeological evidence for the flow of luxury goods toward the west, like the export of Chinese silk, well-known from written sources.

Hepu in Guangxi was not only the seat of the Hepu commandery in the Han period but also a flourishing port in the seaborne trade at that time, and one of the starting points of the maritime Silk Road. The HanShu (chapter 28B) describes regular voyages starting from the Gulf of Tonking ports, Hepu and Xuwen, to several lands in Southeast Asia, finally reaching Huangzhi, which is usually sought in southeast India (Wang 1959: 19-23. Schottenhammer 2006: 611-612). This description makes mention, between months of sailing, of an overland passage of ten days, which is thought to refer to a crossing of the Thai-Malay Peninsula in the Kra Isthmus region (Borell 2010. Borell 2011). The archaeological evidence for such regular contacts has been significantly increased; the objects found at sites on the east and west coast of the Kra Isthmus region in southern Thailand include Chinese bronzes and - most importantly - ceramics of the Han period (Peronnet 2013). The array of finds imported from overseas at these sites signifies their function as way and trading stations along the maritime routes with an overland crossing of the Peninsula.

Recently, fragments of Guangxi style glass cups became known from two sites in southern Thailand just south of the Kra Isthmus, at Ta Chana in Suratthani province on the east coast and at Bang Kluay in Ranong province on the west or Andaman coast (Figure 10). James Lankton carried out the chemical analyses of their glass, which reveal a potash glass of a composition very similar to that of the Guangxi vessels (Lankton et al. 2009). The fragments, though very small, represent probably at least eight individual vessels of the Guangxi type of cups; one fragment comes from Bang Kluay, all the others are from Ta Chana. Presently, our knowledge about the two sites Ta Chana and Bang Kluay in archaeological terms is rather fragmentary owing to a lack of controlled excavations. The material comes from chance finds and uncontrolled digging activities. 


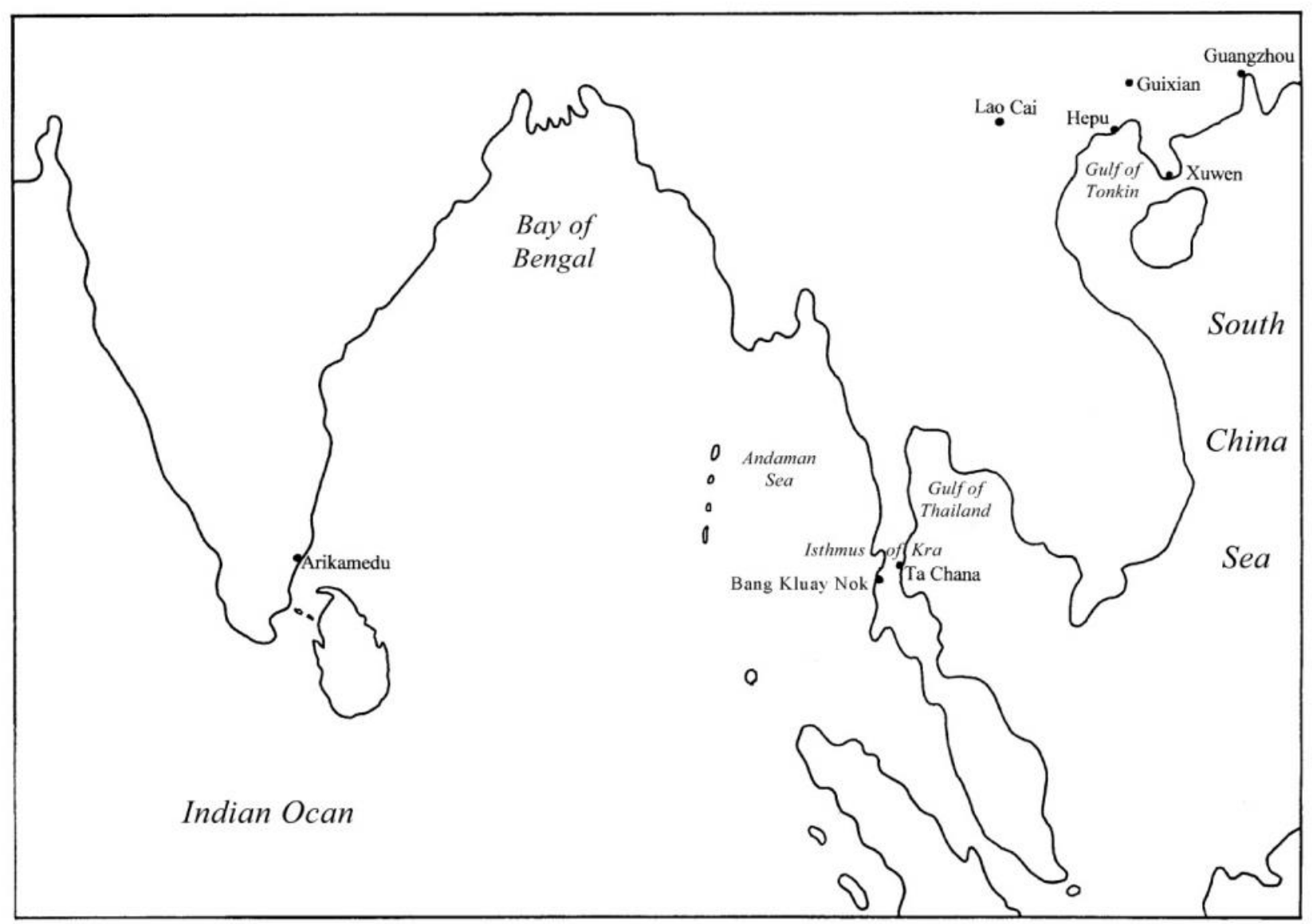

Figure 10. Map showing the sites with finds of glass of the Guangxi group. Drawing by B.Borell and A.Seidel.

Ta Chana, where the majority of these small vessel fragments were found, is considered to have been a beadmaking site, since waste material from bead-making - of stone beads and glass beads - has been discovered (Pongpanich 2009: 105-115; 163-175). It seems that at least the context in which the vessel glass fragments survived was a production site, and fragments of former vessels might have been re-used for other glassworking purposes like making beads. A vessel fragment distorted by heat and apparently handled with a tool seems to support such an interpretation.

Bang Kluay belongs to the Phukao Thong group of sites in the area of the Khlong Kluay estuary system on the Andaman coast (Chaisuwan and Naiyawal 2009: 95). In addition to their role as way and trading stations in maritime and transpeninsular trade, the products of some specialised industries like bead-making might have been offered at these sites. However, in the case of the Phu Khao Thong area, situated in the Southeast Asian tin belt (Schwartz et al. 1995; Pryce et al. 2008: 306-307), a great attraction of the place might have been the tin deposits. Boonyarit Chaisuwan reported the find of a tin ingot from Phu Khao Thong (Chaisuwan 2009; cf. also MurilloBarroso 2010: 1763, 1768-69), and tin might indeed have been of importance as an export commodity from the area. In addition to the finds originating from northern Vietnam and southern China, other objects arrived from western lands, like Rouletted Ware from India, glass from the Mediterranean regions, as well as Roman intaglios and cameos (Chaisuwan and Naiyawal 2009: 94-105. Borell et al. 2014), complementing the picture of extensive, far-reaching trade networks in an eastern and western direction.

\section{CONCLUSION}

The shallow glass bowl form Lao Cai is an important addition to the Guangxi group of glass vessels from the late Western Han and the Eastern Han period. Like the characteristic horned bronze bells from the same find group, the Lao Cai glass bowl is evidence for the distribution of artefacts of similar type and style in the area of Guangxi and northern Vietnam. The precious glass vessels of the Guangxi group, made of potash glass characterised by a low lime content, are probably a product of this region, like the majority of glass artefacts with a similar chemical composition found in the area. This assumption also finds support in the written sources. In addition to the other high prestige items from the Lao Cai find groups, in all likelihood burial contexts, such a precious item as the Lao Cai glass bowl further emphasises 
the high rank of those burials, indicating an important centre of power in the upper Red River valley. The fragments of Guangxi style glass vessels from two sites in southern Thailand and from Arikamedu on the southeast coast of India throw an interesting light on the activities in maritime trade and exchange along the so-called Silk Road of the Sea.

\section{ACKNOWLEDGEMENTS}

This paper, based on an oral presentation at the 19th IPPA Congress Hanoi 2009, was written in 2010. Some more recent publications have been added in the references. My sincere thanks are due to Nguyễn Giang Hải (Hanoi), Phạm Minh Huyền (Hanoi), and Nguyễn Mạnh Cường (Lao Cai) who made it possible for me to study this glass dish in the Museum of Lao Cai Province. I also thank all of the staff in the museum for their kind assistance during my visit in Lao Cai in March 2009. Ulrike Middendorf (Heidelberg) and Chen Liang (Heidelberg) helped me with reading and translating from the Chinese, especially with the amended reading and translating of the inscription on the bronze bell from Lao Cai. I am most grateful to both of them. For help with the translation of the text passage from Ge Hong's Baopu zi nei pian I thank U. Middendorf (Heidelberg) and R. Overbey (Heidelberg and Cambridge, Mass.).. For fruitful discussions and additional information I thank Ulrike Proske (Bremen), Yuko Hirano (Tokio), and, in particular, James Lankton (Seoul) to whom I owe the knowledge of the fragments from southern Thailand and a first opportunity to examine them. Special thanks are due to Bunchar Pongpanich (Bangkok and Nakhon Si Thammarat) for permission to study these fragments from southern Thailand kept in the Suthi Ratana Foundation.

\section{REFERENCES}

Allard, F. 1999. The archaeology of Dian: trends and tradition. Antiquity 73 (279): 77-85.

An Jiayao 1987. Early Chinese Glassware. Oriental Ceramic Society Translations No.12.

Begley, V. 2004. Chronology. In V.Begley (ed.), The Ancient Port of Arikamedu. New Excavations and Researches 1989-1992, vol.2, pp.1-15. Paris: École française d'Extrême-Orient.

Borell, B. 2010. Trade and glass vessels along the Maritime Silk Road. In B.Zorn and A.Hilgner (eds.), Glass along the Silk Road from 200 BC to $A D$ 1000, pp.127-142. Römisch-Germanisches Zentralmuseum - Tagungen, vol.9. Mainz: Römisch-Germanisches Zentralmuseum.

Borell, B. 2011. Han period glass vessels in the early Tongking Gulf region. In N.Cooke, Li Tana and J.A.Anderson (eds.), The Tonking Gulf through History, pp.53-66. Philadelphia: University of Pennsylvania Press.

Borell, B. 2012. Han period glass vessels from the Gulf of Tonking region: aspects of their technology. In D.Igantiadou and A.Antonaras (eds.), Annales $d u 18 e$ Congrès de l'Association Internationale pour l'Histoire du Verre, Thessaloniki, September 2009, pp.491-496. Thessaloniki: ZITI Publishing.
Borell, B., B.Bellina, and B.Chaisuwan 2014. Contacts between the upper Thai-Malay Peninsula and the Mediterranean World. In N. Revire and S. Murphy (eds.), Before Siam: Essays in Art and Archaeology, pp.98-117. Bangkok: River Books.

Brill, R.H. 1999. Chemical Analyses of Early Glasses. Vol.1: Catalogue of Samples. Vol.2: Tables of Analyses. Corning: New York.

Brill, R.H. and H.Shirahata 2009. The second Kazuo Yamasaki TC-17 lecture on Asian glass: recent lead-isotope analyses of some Asian glasses with remarks on strontium-isotope analyses. In Gan Fuxi R.Brill, and Tian Shouyun (eds.), Ancient Glass Research along the Silk Road, pp.149-164. Singapore: World Scientific.

Chaisuwan, B. 2009. The ancient port of Phukhao Thong. Paper presented at the 19th Indo-Pacific Prehistory Association Congress, Hanoi, Vietnam, November 29-December 5, 2009.

Chaisuwan, B. and R.Naiyawal 2009. Thung Tuk: A Settlement Linking together the Maritime Silk Route. Songhkla: Trio Creation.

China Today

2002 , http://www.chinatoday.com.cn/English/e2002/y200212/c4 .htm, accessed June 3, 2010

Falkenhausen, L.v. 2002. The use and significance of ritual bronzes in the Lingnan region during the Eastern Zhou period. Journal of East Asian Archaeology 3: 193-236.

Fan Shimin and Zhou Baozhong 1991. Some glass in the Museum of Chinese History. In R.H. Brill and J.H.Martin (eds.), Scientific Research in Early Chinese Glass. Proceedings of The Archaeometry of Glass Sessions of the 1984 International Symposium on Glass Beijing, September 7, 1984, pp.193-200. Corning, New York: The Corning Museum of Glass.

Fu Xiufeng and Gan Fuxi 2009. Multivariate statistical analysis of some ancient glasses unearthed in southern and southwestern China. In Gan Fuxi, R.Brill, and Tian Shouyun (eds.), Ancient Glass Research along the Silk Road, pp.413-438. Singapore: World Scientific.

Ge Hong (284-343 CE), 1985. Baopuzi Neipian jiao shi (Inner chapters of the master who embraces simplicity, collated and explained), ed. and commented Wang Ming. Beijing: Zhonghua shuju.

Higham, C. 2002. Early Cultures of Mainland Southeast Asia. Bangkok: River Books.

Hirano, Y. 2008. Regional trade and its development in the Iron Age of Vietnam: from the study of glass ornaments. Khảo cổ học/Archaeology 3: 43-49.

Huang Qishan 1992. Guangxi fa xian de Han dai boli qi (Glassware of the Han dynasty discovered in Guang-xi).Wenwu 1992 (9): 46-48.

Huang Qishan 2005. Zhongguo nanfang he xinan de gudai boli jishu (Ancient glass technology in the South and SouthWest of China). In Gan Fuxi (ed.), Zhongguo gudai boli jishu de fazhan (Development of Chinese Ancient Glass), pp.182-199. Shanghai: Shanghai kexue jishu chubanshe.

Huang Qishan 2006. Guangxi Han dai boli yu Yue ren hai shang si chou zhi lu de tan suo (Research into glass of the Han period in Guangxi and into the maritime Silk Road of the Yue people). In Zhongguo guojia bowuguan, Guangxi Zhuangzu Zizhiqu bowuguan (eds.), Ou Luo yi cui: Guangxi Baiyue wen hua wen wu jing pin ji (Treasures 
from $\mathrm{Ou}$ and Luo. A collection of selected cultural relics from the Hundred Yue in Guangxi), pp.268-281. Beijing: Zhongguo shehui kexue chubanshe.

Jiang Tingyu 1984. Yang jiao niu tong zhong chu lun (An initial discussion of bronze bells with sheep's horns). Wenwu 1984 (5): 666-69.

Kwan, S. 2001. Zhongguo gudai boli - Early Chinese glass. Hong Kong: Art Museum, The Chinese University of Hong Kong.

Lankton, J. and L.Dussubieux. 2006. Early glass in Asian maritime trade: A review and an interpretation of compositional analyses. Journal of Glass Studies 48: 121-144.

Lankton, J., B.Pongpanich, B.Chaisuwan, and B.Gratuze. 2009. Chinese Han period glass cup fragments in peninsular Thailand. Paper presented at the 19th Indo-Pacific Prehistory Association Congress, Hanoi, Vietnam, November 29-December 5, 2009.

Li Qinghui, Wang Weizhao, Xiong Zhaoming, Gan Fuxi and Cheng Huansheng 2009. PIXE study on the ancient glasses of the Han Dynasty unearthed from Hepu county, Guangxi. In Gan Fuxi, R.Brill, and Tian Shouyun (eds.), Ancient Glass Research along the Silk Road, pp. 397-411. Singapore: World Scientific.

Lierke, R. 2002. The 'grinding marks' of ancient glass - a critical assessment. Glass Science and Technology 75 (4): 201208.

Lierke, R. 2009. Die nicht-geblasenen Gefäße. The Non-Blown Ancient Glass Vessels. Offenbach/Main: Die Deutsche Glastechnische Gesellschaft.

Loewe, M. 2004. Guangzhou: The evidence of the standard histories from the Shi ji to the Chen shu, a preliminary survey. In S.Müller, T.O.Höllmann and Gui Putao (eds.), Guangdong. Archaeology and Early Texts (Zhou-Tang), pp.51-80. Wiesbaden: Harrassowitz.

Murowchick, R.E. 2002. The political and ritual significance of bronze production and use in ancient Yunnan. Journal of East Asian Archaeology 3: 133-192.

Murillo-Barroso, M., T.O.Pryce, B.Bellina, and M.MartinónTorres 2010. Khao Sam Kaeo - an archaeometallurgical crossroads for trans-asiatic technological traditions. Journal of Archaeological Science 37: 1761-1772.

Nguyễn Việt 2007. Minh văn chữ Hán sớm nhất ở Việt Nam (Minh văn trên đồ đồng Đông Sơn)/Earliest inscriptions in Han (Chinese) characters in Việt Nam (On Đông Sơn cultural bronze items). Khảo cổ hoc/Archaeology 5: 43-51.

Peronnet, S. 2013. Overview of Han artefacts in Southeast Asia with special reference to the recently excavated material from Khao Sam Kaeo in southern Thailand. In M.J. Klokke and V. Degroot (eds.), Unearthing Southeast Asia's Past vol.1, pp. 155-169. Singapore: Singapore University Press.
Phạm Minh Huyền 1997a. Một trung tâm văn minh cổ đại đầu nguồn Sông Hồng ở đất Việt/Dong Son civiliza-tion at the upper Red River of Vietnam. Khảo cổ học/Archaeology 1: 38-63.

Phạm Minh Huyền 1997b. Dong Son drums discovered in Lao Cai town in 1993. Tōnan Ajia Kōkogaku/Journal of Southeast Asian Archaeology 17: 45-59.

Pongpanich, B. 2009. Beyond Beads. Bangkok: Matichon.

Pryce, T.O., B. Bellina-Pryce, and A.T.N. Bennet. 2008. The development of metal technologies in the upper ThaiMalay Peninsula: initial interpretation of the archaeometallurgical evidence from Khao Sam Kaeo. Bulletin de l'École française d'Extrême-Orient 93 [for 2006]: 295316.

Reinecke, A., Lê Duy Sơn, and Lê Đình Phúc 1999. Zur Vorgeschichte im nördlichen Mittelvietnam. Eine Bestandsaufnahme nach vietnamesisch-deutschen Feldforschungen (Về tiền sử Bình-Trị-Thiên (Bắc Trung Bộ Việt Nam). Tình hình nghiên cứu và những nhân xét $b$ ớc đầu qua các đợt điều tra, khảo sát của đoàn khảo cổ học Việt Nam - CHLB Đức). Beiträge zur Allgemeinen und Vergleichenden Archäologie 19: 5-111.

Reinecke, A., Nguyễn Chiều, and Lâm Thị Mỹ Dung 2002. Neue Entdeckungen zur Sa-Huỳnh-Kultur: Das Gräberfeld Gò Mả Vôi und das kulturelle Umfeld in Mittelvietnam (Những phát hiện mới về văn hóa Sa Huỳnh: Khu mộ táng Gò Mả Vôi và vị thế văn hóa của nó ở miền Trung Việt Nam). AVA-Forschungen vol.7. Köln: Linden Soft.

Schottenhammer, A. 2006. Schiffahrt und Überseebeziehungen bis ins 3.Jahrhundert: Ein Überblick. In M.Friedrich (ed.), Han-Zeit. Festschrift für Hans Stumpfeldt aus Anlass seines 65.Geburtstages, pp.599-621. Wiesbaden: Harrassowitz.

Schwartz, M.O., S.S.Rajah, A.K. Askury, P.Putthapiban, and S.Djaswadi. 1995. The Southeast Asian tin belt. EarthScience Reviews 38: 95-293.

Shi Meiguang, He Ouli, and Zhou Fuzheng 1987. Investigation on some Chinese potash glasses excavated in Han Dynasty tombs. In H.C.Bhardwaj (ed.), Archaeometry of Glass. Proceedings of the Archaeometry Session of the XIV International Congress on Glass 1986 New Delhi India, pp.15-20. Calcutta: Indian Ceramic Society.

Wang Gungwu 1959. The Nanhai trade. A study of the early history of Chinese trade in the South China Sea. Journal of the Malaysian Branch of the Royal Asiatic Society 31 (2): 1-135.

Yun Kuen Lee 2001. Status, symbol, and meaning in the Dian Culture. Journal of East Asian Archaeology 3: 103-131. 